DOI: https://doi.org/10.47405/mjssh.v6i8.958

\begin{tabular}{|c|c|}
\hline 4.581 & Malaysian Journal of Social Sciences and Humanities (MJSSH) \\
\hline $\begin{array}{l}\text { Malaysian Journal of } \\
\text { Social cciences and }\end{array}$ & Volume 6, Issue 8, August 2021 \\
\hline (MJ-SSH) & e-ISSN : 2504-8562 \\
\hline & $\begin{array}{l}\text { Journal home page: } \\
\text { www.msocialsciences.com }\end{array}$ \\
\hline
\end{tabular}

\title{
Hubungan Antara Kepuasan Kerja dengan Prestasi Kerja dalam kalangan Guru- Guru Sekolah Menengah Kawasan Pedalaman, Sabah
}

\author{
Zulaine Bin Awang Taul', Mohd Khairuddin@ Jerry Bin Abdullah' \\ ${ }^{1}$ Universiti Malaysia Sabah (UMS) \\ Correspondence: Zulaine Bin Awang Taul (azat8569@gmail.com)
}

\begin{abstract}
Abstrak
Kajian ini bertujuan untuk mengkaji kepuasan kerja dan prestasi kerja dalam kalangan guru-guru sekolah menengah kawasan pedalaman, Sabah. Kajian ini melibatkan seramai 375 orang responden yang terdiri daripada guru-guru yang terlatih dan mereka ini dipilih menerusi persampelan bertujuan dan rawak mudah. Kajian ini berbentuk kuantitatif dan deskriptif serta menggunakan borang soal selidik berkaitan dengan kepuasan kerja dan prestasi kerja. Kajian ini dianalisis dengan menggunakan Statistical Package for Social Science (SPSS). Statistik deskriptif seperti frekuensi, peratusan dan min serta sisihan piawai digunakan dalam kajian ini bagi melihat tahap kedua-dua pemboleh ubah di samping menggunakan analisis korelasi pearson sebagai menguji hipotesis kajian. Dapatan daripada analisis telah mendedahkan skor min bagi tahap keseluruhan kepuasan kerja dan prestasi kerja dalam kalangan guru yang dikaji berada pada tahap yang tinggi. Di samping itu, kajian juga menunjukkan terdapatnya hubungan yang positif dan signifikan antara kepuasan kerja dengan prestasi kerja. Keputusan ini secara langsungnya menolak hipotesis nol yang telah dibina sebelum ini.
\end{abstract}

Kata kunci: kepuasan kerja, prestasi kerja, kawasan pedalaman

\section{The Relationship Between Job Satisfaction and Job Performance Among Teachers in Interior Areas, Sabah}

\begin{abstract}
This study aims to examine job satisfaction and job performance among secondary school teachers in interior areas, Sabah. The study involved a total of 375 respondents consisting of trained teachers and they were selected through purposeful sampling and simple random. This study is quantitative and descriptive and uses questionnaires related to job satisfaction and job performance. This study was analyzed using the Statistical Package for Social Science (SPSS). Descriptive statistics such as frequency, percentage and mean as well as standard deviation were used in this study to see the level of both variables in addition to using pearson correlation analysis as testing the study hypotheses. Findings from the analysis have revealed that the mean score for the overall level of job satisfaction and job performance among the teachers studied is at a high level. In addition, studies also show that there is a positive and significant relationship between job satisfaction and job performance. This result directly rejects the null hypothesis that has been constructed previously.
\end{abstract}


Keywords: job satisfaction, job performance, interior areas.

\section{Pengenalan}

Dalam menentukan kualiti masyarakat di Malaysia, pendidikan dianggap bahagian yang penting dan berperanan dalam memajukan kognitif pelajar di samping sebagai agensi yang melahirkan insan yang seimbang (Samruhaizad \& Azahan, 2017; Mohd Aizat \& Kamarudin, 2020). Ini selaras dengan Mok (2003) bahawa pendidikan adalah agen yang paling berpengaruh dalam menggalakkan proses mobiliti sosial di samping berperanan penting dalam mengembang ekonomi dan menyebar kebudayaan masyarakat. Pendidikan juga mempunyai peranan yang sangat strategik dalam pembangunan negara. Pelbagai jenis kajian di banyak negara menunjukkan pendidikan berkait rapat dengan tahap ekonomi, sosial dan budaya dan ianya sebagai petunjuk kepada pembangunan negara (Amiartuti \& Endang, 2015).

Salah satu komponen pendidikan yang sangat penting dalam merangka pelaksanaan rancangan strategi adalah guru. Ini kerana tunjang bagi semua pendidikan asas adalah guru. Memandangkan guru adalah pembentuk watak dan semangat bangsa, maka kebaikan dan sebaliknya kepada negara sangat bergantung pada mereka (Amiartuti \& Endang, 2015). Oleh itu, guru merupakan salah satu kunci kejayaan dalam mencapai proses pendidikan yang berkualiti. Menjadikan guru sebagai profesion yang sudah semestinya bukan hanya menjadi seseorang yang perlu ditiru, malahan mereka juga berperanan aktif dalam menentukan hala tuju dan tahap kejayaan pendidikan pelajar secara keseluruhan (Rinra Ayu \& Rini, 2017). Di samping itu, menurut Nurlina, Mohd Daud dan Ahmad Nasir (2018) bekerja sebagai seorang guru penting dalam proses pembangunan manusia serta masyarakat dan negara memandangkan ianya juga penting dalam proses penyebaran ilmu kepada masyarakat. Maka tidak dapat dinafikan bahawa dalam menjayakan sesuatu misi serta visi pendidikan, gurulah menjadi jentera penggerak utamanya (Nurlina et al., 2018). Oleh yang sedemikian, sebagai yang bergelar profesional, para guru dikehendaki mengambil tahu berkenaan perkembangan semasa ilmu pengetahuan dan kemahiran terkini agar mampu menyediakan pengalaman yang bermakna terhadap pembelajaran pelajar (Noriati, Boon \& Wong, 2010).

Dalam melaksanakan tugas dan tanggungjawab guru seharian di sekolah, guru-guru yang mengajar sememangnya tidak sunyi dari berhadapan dengan masalah berkaitan tekanan kerja, beban tugas, hubungan rakan sekerja, karenah pelajar dan pelbagai keadaan kemudahan sekolah yang bermacam bentuk. Ini kerana kajian-kajian lepas mendapati aspek-aspek yang dinyatakan tersebut amat berkait rapat dengan kepuasan kerja (Ekpoh, 2018; Dhuryana \& Hussain, 2018; Kyra, 2013; Mazlina, 2013; Usang, 2012) dan aspek kepuasan kerja yang dimiliki oleh guru atau pekerja pula akan mendatangkan kesan kepada prestasi kerja mereka (Agustinus, Sandra \& Basilus, 2019; Halimatussaediyah \& Noraini, 2015; Muhammad Arifin, 2015). Oleh yang demikian, demi melahirkan pelajar yang seimbang dan berpotensi sejajar dengan perkara yang digariskan dalam Falsafah Pendidikan Kebangsaan, maka guru tidak terkecuali juga dari berhadapan dengan pelbagai tahap kepuasan kerja yang boleh dikaitkan dengan prestasi kerja mereka. Menurut Nor Mohamad, Jamalul dan Ruzitah (2016) bahawa guru kini memikul beban yang mencabar disebabkan tanggungjawab yang dianggap oleh masyarakat sering mengalami perubahan. Tugasan yang dipikul ini bukan sahaja meliputi akademik tetapi juga meliputi tugasan bukan mengajar yang akhirnya dibimbangi boleh mempengaruhi kepuasan kerja mereka (Nor Mohamad et al., 2016). Begitu juga, para guru seharusnya sensitif dengan perubahan keadaan terkini serta perlu memberikan kesesuaian dengan bijak dalam menyelesaikan masalah berkaitan pengajaran dan pembelajaran lebih-lebih lagi yang melibatkan disiplin pelajar (Yahya \& Zainuddin, 2003). Namun dalam mengharungi segala permasalahan yang mendatang, para guru seharusnya mempunyai semangat yang kental bagi mendidik pelajar. Ini kerana menurut Mohamed Najib dan M. Noor (2008) seseorang yang telah bergiat dalam profesion ini dengan rasminya mempunyai tanggungjawab di samping menjaga imej dan mengamalkan profesion perguruan ketika melaksanakan tugasan. Oleh itu aspek prestasi kerja dalam kalangan para guru seharusnya diambil perhatian. Ini kerana aspek prestasi kerja tersebut penting dalam memacu pencapaian sesuatu matlamat organisasi. Oleh yang demikian, dalam 
usaha untuk mengekal dan mempertingkatkan prestasi kerja dalam kalangan guru maka faktor yang mendorong ke arah mempertingkatkan kualiti mereka seharusnya diketahui. Antara pemboleh ubah yang sering berkait rapat dengan prestasi kerja adalah aspek kepuasan kerja (Abdullah Sanusi, Ishak \& Ulya, 2018; Li, Perez-Diez, Mao \& Petrides, 2018; Hazriyano, 2017). Lantas berdasarkan pernyataanpernyataan ini maka kajian ini dilaksanakan bagi mengenal pasti tahap kepuasan kerja dan prestasi kerja guru-guru sekolah menengah di kawasan pedalaman, Sabah di samping menentukan sama ada terdapatnya hubungan antara kedua-dua pemboleh ubah tersebut.

\section{Objektif Kajian}

Kajian ini bertujuan untuk menentukan tahap skor min kepuasan kerja dan prestasi kerja di samping melihat hubungan kepuasan kerja dengan prestasi kerja guru-guru sekolah menengah di pedalaman Sabah. Antara objektif dalam kajian ini adalah seperti berikut:

i. Mengenal pasti tahap kepuasan kerja dalam kalangan guru-guru sekolah menengah di kawasan pedalaman, Sabah.

ii. Mengenal pasti tahap prestasi kerja dalam kalangan guru-guru sekolah menengah di kawasan pedalaman, Sabah.

iii. Mengenal pasti hubungan antara kepuasan kerja dengan prestasi kerja dalam kalangan guruguru sekolah menengah di kawasan pedalaman, Sabah.

\section{Hipotesis Kajian}

Hipotesis nol kajian telah dibina seperti berikut:

i. Tidak terdapat hubungan antara kepuasan kerja dengan prestasi kerja dalam kalangan guruguru sekolah menengah di kawasan pedalaman, Sabah.

\section{Sorotan Literatur}

Rinra dan Rini (2017) menyatakan kepuasan kerja sebagai sikap kesenangan atau emosi yang positif dan ianya dihasilkan dari pengukuran kerja berkaitan seberapa baik pekerjaan yang telah mereka laksanakan. Sikap positif seseorang terhadap suatu pekerjaan akan dipamerkan jika mereka mempunyai tingkat kepuasan kerja yang tinggi berbanding seseorang yang tidak puas dengan pekerjaannya akan menunjukkan sikap negatif terhadap pekerjaan mereka. Kepuasan kerja merupakan salah satu faktor yang boleh menggerakkan sikap seseorang. Ini kerana perasaan yang selesa di kalangan guru diperlukan untuk memulakan dan melaksanakan sebarang tugasan dengan sepenuh hati (Mohd. Kassim, 2003). Steers dan Porter (1987) menyatakan antara faktor yang berupaya meningkatkan prestasi dan keberkesanan seseorang dalam melakukan kerjanya ialah aspek kepuasan kerja. Pekerja yang mempunyai kepuasan kerja juga adalah seorang yang bermotivasi tinggi serta berupaya untuk mempertingkatkan lagi hasil serta prestasi kerja untuk mencapai objektif dan matlamat organisasi. Menurut Nurlila (2018) prestasi kerja pula boleh dianggap sebagai gabungan antara kemampuan mental dan fizikal pekerja dalam melakukan sesuatu tugas yang telah diberikan kepada mereka. Ianya meliputi aspek kuantiti dan kualiti yang dianggap sebagai keupayaan pekerja dalam mencapai tahap produktiviti (Nurlila, 2018). Manusia yang berkualiti sering kali dikaitkan dengan mereka yang mempunyai prestasi kerja tinggi dan ianya sangat diperlukan oleh pelbagai institusi sama ada melibatkan kerajaan atau pun pihak swasta (Alri \& Lena, 2015) Lantas pekerja yang mempunyai prestasi kerja yang tinggi akan sentiasa menyedari tanggungjawab masing-masing dan berusaha melaksanakan semua tugas yang diberikan kepadanya dengan betul mengikut kemampuan yang dimiliki untuk mendapatkan hasil kerja yang maksimum. Sebaliknya pekerja yang tidak mempunyai prestasi kerja akan hanya memberi kesan yang tidak baik kepada pekerja itu sendiri serta institusi tempat dia bekerja (Alri \& Lena, 2015). 
Kajian yang dilaksanakan oleh Norsimah dan Mohd Mahadzir (2020) terhadap 440 orang guru yang mengajar di MRSM mendapati tahap prestasi kerja guru yang dikaji berada pada tahap yang tingi. Menurut mereka prestasi kerja dalam kalangan guru hendaklah terus ditingkatkan lagi memandangkan ianya merupakan penentu utama kepada keupayaan guru untuk mencapai matlamat yang telah ditentukan. Hazriyano (2017) pula telah melaksanakan kajian terhadap 179 orang pensyarah universiti di bandar Batam, Indonesia mendapati kepuasan kerja guru-guru yang dikaji adalah salah satu pemboleh ubah yang mempunyai kaitan positif dan signifikan dengan prestasi kerja. Manakala hasil kajian Abdullah Sanusi, Ishak dan Ulya (2018) terhadap hubungan antara kepuasan kerja dengan komitmen, motivasi dan prestasi kerja mendapati nilai min bagi setiap pemboleh ubah yang dikaji adalah di antara 6.06 dan 8.15 dan menunjukkan tahap kepuasan kerja dan prestasi kerja adalah antara dua pemboleh ubah yang mempunyai aras yang tinggi. Hasil kajian juga mendedahkan bahawa kesemua pemboleh ubah dalam kepuasan kerja bertindak sebagai antara penentu utama dalam mempengaruhi komitmen, motivasi dan prestasi seseorang pekerja. Menurut kajian mereka, emosi dan sikap serta motivasi pekerja akan diperbaiki apabila adanya kepuasan kerja dan ini akan memberikan mereka lebih komited dan berprestasi.

Kajian yang dilakukan oleh Fadzin, Mohammad Mujaheed dan Farah (2020) pula mendapati keputusan analisis terhadap prestasi kerja dan kepuasan kerja kaki tangan awam di MAMPU, Putrajaya menunjukkan bahawa tahap untuk kedua-dua pemboleh ubah ini berada pada tahap yang tinggi. Selain itu, kajian terhadap kepuasan kerja dan prestasi kerja dalam kalangan kakitangan Yayasan Pembangunan Keluarga Darul Takzim (YPKDT) di Nusajaya, Johor Bahru telah dijalankan oleh Halimatussaediyah dan Noraini (2015). Kajian mereka ini mendapati adanya hubungan yang signifikan antara kedua-dua pemboleh ubah yang dikaji tersebut. Selain itu kajian juga mendapati tahap kepuasan kerja dan tahap prestasi kerja dalam kalangan kakitangan yang dikaji menunjukkan tahap yang tinggi dengan masing-masing 43 orang mempunyai tahap kepuasan kerja yang tinggi dan hanya 19 orang (30.6\%) berada dalam lingkungan kepuasan kerja yang sederhana dan tahap prestasi kerja mendapati seramai 43 orang (69.4\%) mempunyai tahap prestasi kerja yang tinggi berbanding hanya 19 orang kakitangan atau (30.6\%) berada pada tahap prestasi kerja yang sederhana.

Berdasarkan hasil kajian Muslizah, Siti Noor dan Anis (2020) terhadap kepuasan kerja dan komitmen guru sekolah menengah cemerlang di Kelantan juga mendapati item-item yang terdapat dalam pemboleh ubah kepuasan kerja berada dalam lingkungan tahap min yang sangat tinggi. Dapatan ini menggambarkan andaian bahawa guru-guru telah memperoleh kepuasan daripada kerjaya mereka sebagai seorang guru. Kajian mereka juga mendedahkan aspek kepuasan kerja yang dikaji ini mempunyai hubungan yang signifikan dengan komitmen mereka sebagai guru. Manakala dapatan Kadtong, Unos, Antok dan Midzid (2017) mendapati sebilangan besar guru yang dikaji agak berpuas hati dengan aspek-aspek kepuasan kerja seperti polisi sekolah, penyeliaan, hubungan interpersonal, peluang promosi kenaikan pangkat, keadaan kerja, kerja itu sendiri, pencapaian, pengiktirafan, dan tanggungjawab. Kajian ini juga menunjukkan terdapatnya hubungan yang sederhana kuat antara prestasi pengajaran dengan kepuasan kerja. Oleh itu hipotesis nol yang dirangka oleh mereka adalah ditolak. Tambahan pula, dapatan daripada kajian Li, Perez-Diez, Mao dan Petrides (2018) terhadap pengetua dan guru-guru yang mengajar di tiga puluh tujuh sekolah rendah bandar dan luar bandar wilayah Hubei, China mendapati kepuasan kerja para guru yang dikaji mempunyai hubungan yang berarah positif dengan prestasi kerja. Hasil kajian Baluyos, Rivera dan Baluyos (2019) pula menunjukkan para guru sangat berpuas hati dengan pekerjaan mereka di samping mempunyai prestasi kerja yang juga sangat memuaskan. Para guru berpuas hati disebabkan oleh sokongan dan penyeliaan ketua sekolah mereka. Keadaan kerja yang menyenangkan juga membolehkan para guru membantu antara satu sama lain dalam kerjaya mengajar. Selain itu, dapatan menunjukkan aspek penyeliaan dalam kepuasan kerja mempengaruhi secara negatif prestasi kerja dan aspek keselamatan pula mempengaruhi secara positif terhadap prestasi kerja guru-guru yang dikaji.

Manakala dapatan Rinra dan Rini (2017) mendedahkan kepuasan kerja guru-guru yang dikaji mempunyai pengaruh yang signifikan dan berarah positif terhadap prestasi guru di Sekolah Menengah Kejuruan Negeri dengan analisis korelasi yang tinggi. Dengan peningkatan dalam kepuasan kerja guru akan memberikan peningkatan pula prestasi dalam kalangan guru. Florence (2007) telah menjalankan kajian bagi mengenal pasti hubungan kecerdasan emosi dengan tahap kepuasan kerja dan tahap 
komitmen kerja di kalangan guru bimbingan dan kaunseling sekolah menengah di Bandaraya Kuching, Sarawak. Kajian yang menggunakan 40 orang sampel guru secara rawak mudah telah menunjukkan bahawa tahap kepuasan kerja antara aspek yang dikaji hanya berada pada tahap yang sederhana. Begitu juga dengan kajian terhadap guru-guru program Pendidikan Khas Integrasi Bermasalah Pembelajaran (PKIBP) sekolah rendah di daerah Pontian telah dilaksanakan oleh Mazlina (2013). Dapatan analisis daripada 28 orang guru Pendidikan Khas mendedahkan tahap kepuasan kerja guru yang dikaji juga berada pada tahap yang sederhana. Selain itu, hasil analisis dari dapatan Usang (2012) mendapati tahap kepuasan kerja para guru yang dikaji yang meliputi aspek pelajar, beban tugas dan aspek kemudahan sekolah juga berada pada tahap yang sederhana. Namun dapatan kajian Syed Kamaruzaman, Mohd Faithal dan Habib (2017) pula mendedahkan tahap kepuasan kerja guru Pendidikan Jasmani berada pada tahap yang tinggi bagi aspek hubungan dengan rakan sekerja, aspek gaji dan elaun, hubungan dengan pihak atasan, pencapaian objektif pengajaran, tempat kerja, penyeliaan pegawai atasan, dan peluang kenaikan pangkat berada pada tahap yang rendah. Pada pendapat mereka, rakan sekerja berperanan penting dalam melaksanakan pengajaran pendidikan jasmani dan apabila proses pengajaran dapat dilaksanakan dengan baik maka secara tidak langsung akan meningkatkan pula aspek kepuasan kerja guru.

\section{Metod Kajian}

Dalam kajian ini, kaedah penyelidikan adalah berbentuk kuantitatif dan menggunakan kajian deskriptif berbentuk tinjauan. Penyelidikan deskriptif bermatlamat untuk memberikan penerangan kepada sesuatu fenomena yang sedang berlaku (Mohd. Majid, 2000). Manakala kaedah tinjauan menurut Blake dan Champion (1976) pula adalah salah satu cara yang spesifik untuk mengumpul maklumat berkenaan sekumpulan populasi. Pendekatan tinjauan juga dipilih memandangkan ianya satu kaedah yang mudah dan maklumat diperoleh berdasarkan soal selidik (Mohd. Najib, 2003).

Dalam kajian ini populasi kajian hanya terdiri daripada guru-guru daripada 19 buah sekolah menengah kebangsaan yang dikategorikan sebagai kawasan pedalaman, Sabah sahaja. Pemilihan sampel dalam kajian ini adalah berdasarkan persampelan bertujuan dan rawak mudah. Menurut Chua (2006) persampelan bertujuan merujuk satu prosedur persampelan ke atas sekumpulan subjek yang dipilih dan mempunyai ciri-ciri tertentu dipilih sebagai responden kajian. Sampel kajian yang diperoleh untuk kajian ini adalah seramai 375 orang guru daripada populasi guru keseluruhan. Bilangan sampel ini lebih mencukupi dan ianya bertepatan dengan jadual penentuan saiz sampel Krejcie dan Morgan (1970). Soal selidik telah digunakan dalam mendapatkan data dalam kajian ini. Menurut Mohd. Majid (2000) borang soal selidik digunakan bagi memperoleh data terutamanya dengan penggunaan sampel yang besar. Mohd. Najib (2003) pula menyatakan bahawa instrumen berbentuk soal selidik memberikan pengkaji mendapat jawapan tingkah laku melalui jawapan bertulis di samping ianya terkenal dengan menampilkan soalan atau item yang memberi kemudahan kepada responden memberi jawapan. Menurut Mohd. Majid (2000) peggunaan soal selidik adalah popular disebabkan penggunaannya yang praktikal dan berkesan.

Instrumen kajian berbentuk soal selidik ini meliputi soal selidik yang berkaitan kepuasan kerja dan dibina oleh Usang (2012) berdasarkan kajian lepas yang terdiri daripada tiga aspek kepuasan kerja iaitu aspek pelajar, aspek beban tugas dan aspek kemudahan sekolah. Manakala soal selidik prestasi kerja yang telah dibentuk oleh Strauss dan Sayles (1981) dan telah diadaptasi dan diubahsuai dalam kajian Mohamad Zakaria (2005). Soal selidik prestasi kerja ini merangkumi tujuh dimensi yang melibatkan pengetahuan tentang kerja, sikap, membuat pertimbangan, delegasi, kecekapan peribadi, kebolehan merancang dan kepimpinan. Kedua-dua jenis soal selidik menggunakan skala likert berbentuk lima mata iaitu 1 untuk sangat tidak setuju hingga 5 iaitu sangat setuju. Data dianalisis dengan menggunakan frekuensi, min dan sisihan piawai (SD) di samping teknik statistik inferensi seperti korelasi pearson untuk menguji hipotesis kajian yang dibentuk. Tahap taburan min yang diperoleh akan dikategorikan mengikut tiga tahap (Landell, 1997; Jamil, 2002; Yusof, 2007) iaitu rendah (1.00 $2.33)$, sederhana $(2.34$ - 3.66) dan tinggi $(3.67$ - 5.00). Manakala kekuatan korelasi antara dua pemboleh ubah yang terlibat akan diukur menerusi indeks pekali korelasi daripada Borg dan Gall 
(1983) iaitu 0.01 hingga 0.09 (boleh diabaikan), 0.10 hingga 0.29 (rendah), 0.30 hingga 0.49 (sederhana), 0.50 hingga 0.69 (kuat) dan 0.70 atau lebih (sangat kuat).

\section{Dapatan Kajian}

\section{Analisis Skor Min Kepuasan Kerja Dalam Kalangan Guru}

Jadual 1 menunjukkan tahap min kepuasan kerja dalam kalangan guru kawasan pedalaman, Sabah yang dikaji. Tahap kepuasan kerja pada keseluruhannya berada pada aras min yang tinggi iaitu $\min =3.69$ dan $\mathrm{SD}=0.45$. Tahap kepuasan kerja mengikut aspek-aspeknya pula mendapati aspek pelajar adalah $(\mathrm{min}=$ $3.97, \mathrm{SD}=0.46)$, aspek beban tugas $(\min =3.85, \mathrm{SD}=0.56)$ dan aspek kemudahan sekolah hanya berada pada lingkungan aras yang sederhana $(\min =3.33, \mathrm{SD}=0.68)$. Skor min kepuasan kerja yang diperoleh pada keseluruhan dan mengikut aspek berkaitan pelajar dan beban tugas adalah pada aras yang tinggi mengikut persepsi para guru yang dikaji.

Jadual 1: Analisis Skor Min Keseluruhan Kepuasan Kerja dan Mengikut Aspek

\begin{tabular}{llr}
\hline \multicolumn{1}{c}{ Kepuasan Kerja } & \multicolumn{2}{c}{ Min Sisihan Piawai (SD) } \\
\hline Aspek Pelajar & 3.97 & 0.46 \\
Aspek Beban Tugas & 3.85 & 0.56 \\
Aspek Kemudahan Sekolah & 3.33 & 0.68 \\
Keseluruhan & 3.69 & 0.45 \\
\hline
\end{tabular}

\section{Analisis Skor Min Prestasi Kerja}

Jadual 2 menunjukkan hasil analisis tahap min prestasi kerja dalam kalangan guru kawasan pedalaman, Sabah yang dikaji. Menerusi jadual yang dipaparkan, tahap prestasi kerja para guru yang dikaji pada keseluruhannya berada pada tahap tinggi iaitu $\min =3.86$ dan $\mathrm{SD}=0.34$. Tahap prestasi kerja guru yang dikaji mengikut dimensinya pula memaparkan dimensi pengetahuan tentang kerja adalah $(\mathrm{min}=3.83$ dan $\mathrm{SD}=0.52$ ), dimensi sikap ( $\min =3.96, \mathrm{SD}=0.43)$, dimensi membuat pertimbangan $(\min =3.82, \mathrm{SD}=0.48)$, dimensi delegasi $(\min =3.97, \mathrm{SD}=0.48)$, dimensi kecekapan peribadi $(\min =3.78, \mathrm{SD}=0.49)$, kebolehan merancang $(\min =3.60, \mathrm{SD}=0.49)$, manakala dimensi kepimpinan min adalah $(3.98, \mathrm{SD}=0.50)$. Skor min prestasi kerja yang diperoleh pada keseluruhan dan mengikut dimensi prestasi kerja adalah berada pada tahap yang tinggi dan hanya dimensi kebolehan merancang berada pada aras yang sederhana.

Jadual 2: Analisis Skor Min Keseluruhan Prestasi Kerja dan Mengikut Dimensi

\begin{tabular}{lll}
\hline \multicolumn{1}{c}{ Prestasi Kerja } & Min Sisihan Piawai \\
\hline Pengetahuan Tentang Kerja & 3.83 & 0.52 \\
Sikap & 3.96 & 0.43 \\
Membuat Pertimbangan & 3.82 & 0.48 \\
Delegasi & 3.97 & 0.48 \\
Kecekapan Peribadi & 3.78 & 0.49 \\
Kebolehan Merancang & 3.60 & 0.49 \\
Kepimpinan & 3.98 & 0.50 \\
Keseluruhan & 3.86 & 0.34 \\
\hline
\end{tabular}

\section{Hubungan Kepuasan Kerja dengan Prestasi Kerja}

Dalam menentukan sama ada terdapatnya hubungan antara kepuasan kerja dengan prestasi kerja dalam kalangan guru maka analisis korelasi pearson (r) telah digunakan. Analisis ini dijalankan bagi menjawab hipotesis nol yang telah dibina. Jadual 3 di bawah menunjukkan bahawa hasil analisis kajian mendedahkan terdapatnya hubungan yang positif dan signifikan antara kepuasan kerja dengan 
prestasi kerja yang dikaji iaitu pada aras $\mathrm{p}<.05(\mathrm{r}=.548)$. Aras hubungan ini mendedahkan secara keseluruhannya berada pada tahap yang kuat. Ini menggambarkan bahawa prestasi kerja para guru yang dikaji akan meningkat sejurus berlakunya peningkatan dalam kepuasan kerja. Begitu juga dengan setiap aspek dalam kepuasan kerja yang mempunyai hubungan yang positif dan signifikan dengan pemboleh ubah prestasi kerja.

Jadual 3: Analisis Korelasi antara Kepuasan Kerja dan Aspeknya dengan Prestasi Kerja

\begin{tabular}{ccc}
\hline & & $\begin{array}{c}\text { Prestasi } \\
\text { Kerja }\end{array}$ \\
\hline Kepuasan & Pearson Correlation & $.548^{* *}$ \\
kerja & Sig. (2-tailed) & .000 \\
Aspek & Pearson Correlation & $.560^{* *}$ \\
pelajar & Sig. (2-tailed) & .000 \\
Aspek beban & Pearson Correlation & $.436^{* *}$ \\
tugas & Sig. (2-tailed) & .000 \\
Aspek & Pearson Correlation & $.345^{* *}$ \\
kemudahan & Sig. (2-tailed) & .000 \\
\hline
\end{tabular}

** Korelasi signifikan pada aras 0.01 (2 hujung).

\section{Perbincangan Kajian}

Dapatan daripada analisis deskriptif guru-guru sekolah menengah kawasan pedalaman yang dikaji telah mempersepsikan bahawa tahap kepuasan kerja mereka berada dalam lingkungan yang tinggi. Keadaan ini menggambarkan mereka mempunyai sikap dan perasaan yang positif serta berpuas hati dalam melaksanakan tugasan harian mereka dalam bidang pendidikan. Begitu juga dengan persepsi mereka dalam aspek yang berkaitan dengan kepuasan kerja juga menunjukkan tahap yang tinggi dalam aspek pelajar dan aspek beban tugas. Ini menggambarkan guru berpuas hati dengan sikap yang ditunjukkan oleh pelajar mereka sewaktu proses pengajaran dan pembelajaran berlaku. Di samping itu, mereka juga mempunyai sikap yang komited terhadap tanggungjawab yang diberikan kepada mereka terutamanya yang melibatkan tugasan pengajaran. Namun guru-guru mengalami kepuasan kerja yang hanya sederhana pada aspek kemudahan yang ada di sekolah. Ini menunjukkan bahawa guru-guru mempunyai persepsi yang sederhana dalam kepuasan kerja mereka berkaitan kelengkapan kemudahan yang telah disediakan. Dapatan Kyara (2013) terhadap guru-guru yang dikaji di Kinondoni Tanzania menjelaskan keterbatasan bahan pengajaran dan pembelajaran serta kekurangan perpustakaan di sekolah memberi kesan kepada rendahnya kepuasan kerja guru. Menurut Mohd Kassim (2003) kepuasan kerja merupakan salah satu faktor yang boleh menggerakkan sikap seseorang. Ini disebabkan perasaan yang selesa dalam kalangan guru diperlukan untuk memulakan dan melaksanakan sebarang tugasan dengan sepenuh hati mereka. Maka dengan adanya kepuasan kerja dalam kalangan guru akan membuatkan guru bertahan dalam organisasi mereka. Menurut kajian Shah dan Jumani (2015) dan Ekabu, Kalai dan Nyagah (2018), niat para guru untuk meninggalkan pekerjaan mereka adalah berkaitan dengan aspek kepuasan kerja dan keadaan kerja yang melibatkan keadaan gaji, keadaan pekerjaan itu sendiri, penyeliaan, promosi kenaikan pangkat, keadaan kemudahan sekolah dan pencapaian pelajar.

Dapatan kajian ini juga selari dengan beberapa dapatan kajian terdahulu sama ada dalam bidang perguruan atau bidang lain seperti hasil kajian Abdullah Sanusi et al. (2018) mengenai hubungan antara kepuasan kerja dengan komitmen, motivasi dan prestasi kerja yang mendapati nilai min bagi pemboleh ubah kepuasan kerja mempunyai aras yang tinggi. Begitu juga kajian yang dilakukan oleh Fadzin et al. (2020) yang mendapati keputusan analisis terhadap kepuasan kerja kaki tangan awam yang dikaji menunjukkan tahap untuk pemboleh ubah ini berada pada tahap yang juga tinggi. Selain itu, kajian ini juga selari dengan Halimatussaediyah dan Noraini (2015) yang mendapati tahap kepuasan kerja kaki tangan yang dikaji berada dalam aras yang tinggi. Sejajar dengan itu, hasil kajian Muslizah et al. (2020) terhadap kepuasan kerja dan komitmen guru sekolah menengah cemerlang di Kelantan juga mendapati item-item yang terdapat dalam pemboleh ubah kepuasan kerja berada dalam 
lingkungan tahap min yang sangat tinggi. Dapatan mereka ini memberikan gambaran bahawa guruguru yang dikaji telah memperoleh kepuasan daripada kerjaya mereka sebagai seorang guru. Namun dapatan kajian ini berbeza dengan kajian Florence (2007) yang telah menjalankan kajian ke atas guru bimbingan dan kaunseling sekolah menengah dan mendapati tahap kepuasan kerja hanya berada pada tahap yang sederhana. Begitu juga dengan kajian Mazlina (2013) terhadap guru-guru program Pendidikan Khas Integrasi Bermasalah Pembelajaran (PKIBP) yang hanya mendapati tahap kepuasan kerja guru yang dikaji juga berada pada tahap yang sederhana. Perbezaan dapatan ini besar kemungkinan disebabkan oleh penggunaan sampel kajian yang berbeza dan hanya sedikit sampel yang digunakan.

Selain itu, dapatan kajian analisis deskriptif juga mendapati tahap keseluruhan prestasi kerja yang ditunjukkan oleh para guru yang dikaji ini berada pada tahap yang tinggi. Dapatan ini memberikan gambaran bahawa para guru yang terlibat dalam kajian ini telah mencapai kualiti dan kuantiti kerja di sekolah mereka. Ini selaras dengan penjelasan Siti Hikayah bahawa prestasi kerja itu merujuk kepada kualiti hasil dan kuantiti hasil sebagai unsur utama. Menurut Nurlila (2018) prestasi kerja dianggap sebagai gabungan antara kemampuan mental dan fizikal pekerja dalam melakukan sesuatu tugas yang telah diamanahkan kepada mereka. Ianya meliputi aspek kuantiti dan kualiti yang dianggap sebagai keupayaan pekerja dalam mencapai tahap produktiviti. Pekerja yang mempunyai prestasi kerja yang tinggi sentiasa menyedari tanggungjawab mereka dan akan berusaha melaksanakan semua tugas dengan betul mengikut kemampuan yang dimiliki untuk mendapatkan hasil kerja yang maksimum. Ini berbanding dengan pekerja tidak mempunyai prestasi kerja akan hanya memberi kesan negatif kepada pekerja dan organisasi tersebut (Alri \& Lena, 2015). Oleh itu, menurut Mamat (2016) kewujudan guru yang mempunyai kemampuan mengajar dan mempunyai prestasi yang tinggi memungkinkan untuk memberi nilai positif dalam mencapai tujuan yang dikehendaki.

Dapatan kajian ini selari dengan dapatan dalam pelbagai bidang seperti Halimatussaediyah dan Nuraini (2015) yang mendapati kaki tangan yang dikaji lebih ramai memperoleh tahap prestasi kerja yang tinggi jika dibandingkan dengan mereka yang bertahap sederhana. Begitu juga dengan dapatan Mohd Mahadzir (2017) yang mendapati tahap prestasi kerja guru-guru yang mengajar di MRSM di Malaysia juga berada dalam tahap yang tinggi. Selain itu, menurut Muhammad Amin, Rahmat, Muhammad Ayaz dan Malik (2013) mereka yang mempunyai tahap prestasi kerja yang baik antaranya dilambangkan sebagai berkemampuan untuk mengendalikan proses pengajaran mengikut kemampuan pelajar serta bertindak adil dalam membuat penilaian terhadap pelajar juga menggambarkan mereka yang mempunyai prestasi kerja yang tinggi. Dapatan kajian keseluruhan Rosnah dan Siti Nur (2018) menunjukkan guru memberi persepsi yang tinggi terhadap prestasi kerja mereka di Sekolah Harapan Negara. Mereka juga cuba dengan sedaya upaya untuk meningkatkan prestasi kerja di samping dapat mengekalkan disiplin dalam kelas serta menghadiri kelas mereka sepertimana masa yang telah ditentukan apabila berada di sekolah. Kajian yang dilakukan oleh Fadzin et al. (2020) juga mendapati keputusan analisis terhadap prestasi kerja menunjukkan tahap yang tinggi. Namun dapatan kajian ini bertentangan dengan kajian yang dilaksanakan oleh Nadiah, Amizawati, dan Siti (2019) dan Mohamad Zakaria (2005) yang mendapati prestasi kerja guru sekolah yang mereka kaji hanya berada pada tahap yang sederhana. Oleh itu, Asfar, Syahrir dan Zahari (2015) menyarankan supaya guru memiliki prestasi kerja yang mampu merealisasikan harapan dan keinginan masyarakat umum yang mempercayai bahawa sekolah dan guru tempat membentuk para pelajar. Prestasi kerja guru juga menjadi tuntutan penting dan menjadi kayu ukur dalam mencapai mutu keberhasilan pendidikan.

Dapatan kajian ini juga menunjukkan secara keseluruhannya kepuasan kerja mempunyai hubungan positif yang kuat dengan prestasi kerja guru-guru kawasan pedalaman yang dikaji. Ini menggambarkan bahawa semakin tinggi kepuasan kerja maka semakin tinggi juga prestasi kerja dalam kalangan guru. Hubungan signifikan yang positif ini telah disumbangkan oleh beberapa aspek yang terlibat dalam kepuasan kerja yang merangkumi aspek pelajar, aspek beban tugas dan aspek kemudahan sekolah. Dapatan kajian ini bermakna guru merasa senang dengan persekitaran pelajar yang tekun belajar di samping saling menghormati guru mereka. Begitu juga dengan kepuasan kerja dari aspek beban tugas yang tidak terlalu membebankan dan mampu dilaksanakan oleh mereka boleh mendatangkan kepuasan kerja. Keadaan ini telah menyebabkan meningkatnya prestasi kerja para guru yang dikaji. Menurut Mohamed Najib dan M. Noor (2008) seseorang yang telah bergiat dalam profesion ini dengan 
rasminya mempunyai tanggungjawab di samping menjaga imej dan mengamalkan profesion perguruan ketika melaksanakan tugasan. Kepuasan kerja dari aspek kemudahan sekolah juga mendedahkan adanya hubungan yang positif dan sederhana kuat dengan prestasi kerja. Ini menggambarkan bahawa penyediaan terhadap fasiliti dan kelengkapan sekolah yang baik adalah penting dan seharusnya dipertingkatkan lagi memandangkan ianya mampu untuk menambahkan kepuasan dan prestasi kerja guru. Oleh yang demikian, Steers dan Porter (1987) menyatakan kepuasan kerja merupakan antara faktor yang berupaya meningkatkan prestasi dan keberkesanan seseorang dalam melakukan kerjanya. Pekerja yang mempunyai kepuasan kerja juga dianggap bermotivasi tinggi dan berupaya memaksimumkan lagi hasil serta prestasi kerja untuk mencapai objektif dan matlamat organisasi.

Dapatan kajian ini juga selari dengan hasil kajian terdahulu seperti yang dilakukan oleh Arop, Owen dan Ibor (2019) terhadap guru sekolah menengah di Cross River State, Nigeria mendapati adanya hubungan yang signifikan antara kualiti fasiliti sekolah dengan prestasi kerja guru yang dikaji. Kualiti yang ditunjukkan oleh sekolah akan mempengaruhi cara guru melaksanakan tugasnya. Sekolah dengan kualiti yang baik akan mencerminkan aktivitinya dan meningkatkan prestasi kerja yang lebih baik kepada guru. Ringkasnya, boleh dikatakan bahawa guru memerlukan kemudahan sekolah untuk mengajar dan menyediakan persekitaran yang baik untuk pelajar. Begitu juga dengan dapatan Rinra dan Rini (2017) mendedahkan kepuasan kerja guru-guru yang dikaji mempunyai pengaruh yang signifikan dan berarah positif terhadap prestasi guru. Dapatan analisis juga mendedahkan adanya korelasi yang tinggi antara pemboleh ubah yang berkaitan. Peningkatan yang berlaku dalam kepuasan kerja guru akan memberikan peningkatan pula kepada prestasi dalam kalangan guru. Seterusnya dapatan kajian ini juga sejajar dengan Hazriyano (2017) yang telah mendapati pemboleh ubah kepuasan kerja guru-guru yang dikaji mempunyai kaitan yang positif dan signifikan dengan prestasi kerja. Hasil kajian Abdullah Sanusi et al. (2018) juga mendedahkan adanya hubungan antara kepuasan kerja dengan komitmen, motivasi dan prestasi kerja. Dapatan kajian juga mendedahkan bahawa kesemua faktor dalam kepuasan kerja bertindak sebagai penentu dalam mempengaruhi komitmen, motivasi dan prestasi seseorang pekerja. Menurut mereka lagi, emosi dan sikap serta motivasi pekerja akan diperbaiki apabila adanya kepuasan kerja dan ini akan memberikan mereka lebih komited dan berprestasi. Kepuasan kerja mencerminkan perasaan pekerja terhadap pekerjaan mereka yang dapat dilihat pada sikap positif pekerja terhadap pekerjaan mereka. Sementara pekerja yang tidak mendapat kepuasan kerja akan menyebabkan sikap agresif atau sebaliknya dan akan menunjukkan penarikan diri dari hubungan dengan persekitaran sosial mereka (Edy, 2011). Oleh yang demikian, seseorang dengan tahap kepuasan kerja yang tinggi menunjukkan sikap positif terhadap pekerjaan tersebut dan seseorang yang tidak berpuas hati dengan pekerjaannya menunjukkan sikap negatif terhadap pekerjaan yang mereka miliki (Rinra \& Rini, 2017).

\section{Kesimpulan}

Keputusan kajian ini menunjukkan bahawa kepuasan kerja dan prestasi kerja menampakkan tahap yang tinggi dalam kalangan guru-guru pedalaman yang dikaji. Ini menggambarkan bahawa guru-guru yang dikaji telah menunjukkan komitmen yang tinggi terhadap organisasi mereka. Namun sedemikian dalam usaha untuk mengekalkan tahap yang baik dan berterusan dalam kedua-dua pemboleh ubah ini maka guru di sekolah perlu mendapat sokongan daripada semua pihak dalam organisasi. Ini kerana aspek-aspek dalam kepuasan kerja juga mempunyai kaitan dengan tahap prestasi kerja mereka. Dapatan mendedahkan adanya perkaitan antara aspek pelajar, beban tugas dan kemudahan sekolah dalam kepuasan kerja dengan prestasi kerja. Ini memberi gambaran bahawa perlakuan tingkah laku yang baik dan saling hormat guru dalam kalangan pelajar terhadap guru mampu menimbulkan kepuasan kerja yang akhirnya memberikan prestasi yang baik kepada guru. Begitu juga dengan aspek beban tugas terutama yang berkaitan dengan pengajaran telah memberikan kepuasan kepada guru. Ini bererti beban yang diberikan kepada mereka mampu dikendalikan dengan baik. Oleh yang demikian, dalam mengekalkan tahap kepuasan kerja ini maka beban kerja yang diberikan kepada guru haruslah adil dan mengikut kemampuan mereka. Kepuasan kerja dalam aspek kemudahan sekolah juga mempunyai tahap dan kaitan yang sederhana dengan prestasi kerja. Oleh itu, aspek kemudahan ini haruslah disediakan dengan baik dan mencukupi bagi membolehkan para guru melaksanakan tugasan 
mereka dengan lebih berkesan. Ini kerana keberadaan aspek kemudahan ini akan memberikan tahap kepuasan kerja yang sewajarnya.

\section{Rujukan}

Abdullah Sanusi Othman, Ishak Abd Rahman \& Ulya Sabirah Mohd Hanafi. (2018). Hubungan Antara Kepuasan Kerja dengan Komitmen, Motivasi dan Prestasi Kerja. International Journal of Modern Trends in Business Research (IJMTBR), 1(3), 29-46.

Agustinus Kia Wolomasi, Sandra Ingried Asaloei \& Basilius Redan Werang. (2019). Job Satisfaction and Performance of Elementary School Teachers. International Journal of Evaluation and Research in Education, 8(4), 575-580.

Alri Yogi \& Lena Farida. (2015). "Pengaruh Motivasi Kerja terhadap Prestasi Kerja Karyawan pada PT. Wirastuti Kabupaten Siak." Jurnal Online Mahasiswa Fakultas Ilmu Sosial dan Ilmu Politik Universitas Riau, 2(2), 1-11.

Amiartuti Kusumaningtyas \& Endang Setyawati. (2015). Teacher Performance of The State Vocational High School Teachers in Surabaya. International Journal of Evaluation and Research in Education (IJERE), 4(2), 76-83.

Arop, F. O, Owan, V. J, \& Ibor I. O. (2019). School Quality Indicators and Secondary School Teachers Job Performance in Cross River State, Nigeria. International Journal of Education and Evaluation, 5(3), 19-28.

Asfar Amir, Syahrir @ Chairil bin Hj. Marzuki dan Zahari Bin Hashim.(2015). Pengaruh Kompetensi Guru Terhadap Prestasi Kerja Guru Sekolah Menengah Atas Negeri Di Kota Pariaman Sumatera Barat. Management Research Journal, 5(1), 103-118.

Baluyos, G. R., Rivera, H. L., \& Baluyos, E. L. (2019). Teachers' Job Satisfaction and Work Performance. Open Journal of Social Sciences, 7, 206-221.

Blake, J. A. \& Champion, D. J. (1976). Method and Issues in Social Research. New York: John Willey and Sons.

Borg, W.R. \& Gall, M.D. (1983). Educational Research: An Introduction, Fifth Edition. New York: Longman.

Chua Yan Piaw. (2006). Asas Statistik Penyelidikan Buku 2. Kuala Lumpur: Mc Graw Hill Education.

Dhuryana, A. S., \& Hussain, F. (2018). The Effecting Job Security and Work Load on Job Satisfaction of Teachers Among Higher Education Institution in Southern Punjab. In Proceedings of the 3rd International Conference on Emerging Trends in Engineering, Management and Sciences. October 18-20 (ICETEMS-2018) Peshawar, Pakistan.

Edy Sutrisno. (2011). Manajemen Sumber Daya Manusia, Kencana, Jakarta.

Ekabu, P. K., Kalai, J. M. \& Nyagah, G. (2018). Influence of Working Condition on Turnover Intentions of Secondary School Teacher in Meru Country. European Scientific Journal, 14(25), 169-189.

Ekpoh, U. I. (2018). Teachers' Satisfaction with Physical Working Environment: Imperative for Effective Service Delivery. Journal of Education and Human Development, 7(1), 92-97.

Fadzin Nazirin Bin Mihat, Mohammad Mujaheed Hassan \& Farah Husna Anwar. (2020). Perkaitan antara Motivasi dan Prestasi Kerja Terhadap Kepuasan Kerja dalam Kalangan Penjawat Awam. Malaysian Journal of Social Sciences and Humanities (MJSSH), 5(10), 34-57.

Florence Fletcher. (2007). Hubungan Tahap Kecerdasan Emosi dengan Tahap Kepuasan Kerja dan Tahap Komitmen Kerja di Kalangan Guru Bimbingan dan Kaunseling Sekolah Menengah di Bandaraya Kuching, Sarawak. Masters Thesis, Universiti Teknologi Malaysia.

Halimatussaediyah Tamri \& Noraini Abdol Raop. (2015). Kepuasan Kerja: Hubungannya dengan Prestasi Kerja dalam Kalangan Kakitangan Yayasan Pembangunan Keluarga Darul Takzim (Ypkdt), Nusajaya, Johor Bahru (Job Satisfaction: The Correlation With Job Performance Among Staffs in Ypkdt, Nusajaya, Johor Bahru). Journal Of Human Capital Development (Jhcd), 8(2), 114-129.

Hazriyano. (2017). Komitmen Organisasi, Kepuasan Kerja Dan Prestasi Kerja Dalam Kalangan Pensyarah Universiti Di Kota Batam Indonesia. Tesis Doktor Falsafah. Pendidikan Fakulti Pendidikan Teknikal dan Vokasional, Universiti Tun Hussein Onn Malaysia. 
Jamil Ahmad. (2002). Pemupukan Budaya Penyelidikan di Kalangan Guru Sekolah: Satu Penilaian. Tesis Doktor Falsafah: Universiti Kebangsaan Malaysia.

Kadtong, M. L., Unos, M., Antok, T. D., \& Midzid, M. A. E. (2017). Teaching Performance and Job Satisfaction Among Teachers at Region XII. Proceedings Journal of Education, Psychology and Social Science Research, 4(1), 113-122.

Krejcie, R., \& Morgan, D. (1970). Determining Sample Size for Research Activities. Educational and Psychological Measurement, 30, 607-610.

Kyara, T. E. (2013). The Effect of Primary School Teachers' Job Satisfaction on Their Work Performance in Kinondoni District, Tanzania. Doctoral Dissertation. The Open University of Tanzania.

Landell K. (1997). "Management by Menu." London: Wiley and Sons Inc.

Li, M., Pérez-Díaz, P. A., Mao, Y., \& Petrides, K. V. (2018). A Multilevel Model of Teachers' Job Performance: Understanding the Effects of Trait Emotional Intelligence, Job Satisfaction, and Organizational Trust. Frontiers in Psychology, 9, 2420.

Mazlina Binti Sulaiman. (2013). Hubungan Tekanan Kerja Dengan Komitmen Dan Kepuasan Kerja Dalam Kalangan Guru Program Pendidikan Khas Integrasi Bermasalah Pembelajaran Di Empat Buah Sekolah Rendah Daerah Pontian. Tesis Sarjana Pendidikan: Universiti Teknologi Malaysia.

Mohamad Zakaria Bin Mat Khazani. (2005). Hubungan antara Iklim Organisasi dan Prestasi Kerja di kalangan Guru Matematik Sekolah Rendah di Semenanjung Malaysia. Tesis Doktor Falsafah, Universiti Malaya.

Mohamed Najib Abdul Ghafar \& M. Noor Ariffin (2008). Kesan Latihan Perguruan ke atas Faktor Pemilihan Perguruan. Sains Humanika, 48(1), 15-31.

Mohd Aizat Abu Hassan \& Kamarudin Musa. (2020). Tahap Profesionalisme Guru Sekolah Kebangsaan di Semenanjung Malaysia. Levels of Primary School's Teacher Professionalism In Penisular Malaysia. Management Research Journal, 9 (2), 37-45 37.

Mohd Kassim Ibrahim. (2003). Perkaitan Gaya Kepemimpinan Pengetua dengan Kepuasan Kerja dan Pengajaran Guru. Tesis Doktor Falsafah, Universiti Malaysia Sabah.

Mohd Mahadzir Rahimi Mohamed Nawi. (2017). Iklim Sekolah, Efikasi Kendiri dan Prestasi Kerja Guru Di Sekolah Berprestasi Tinggi Malaysia-Kajian Ke Atas MRSM. Tesis Doktor Falsafah, Universiti Malaysia Sabah.

Mohd Majid Konting. (2000). Kaedah Penyelidikan Pendidikan. Kuala Lumpur: Dewan Bahasa Dan Pustaka.

Mohd. Najib Abdul Ghafar. (2001). Penyelidikan Pendidikan. Skudai: Fakulti Pendidikan, Universiti Teknologi Malaysia.

Muhammad Amin, Rahmat ullah Shah, Muhammad Ayaz, \& Malik Amer Atta. (2013). Teachers' Job Performance at Secondary Level in Khyber Pakhyunkhwa, Pakistan. Gomal University Journal of Research, 29(2), 100-104.

Muhammad Arifin, H. (2015). The Influence of Competence, Motivation, and Organisational Culture to High School Teacher Job Satisfaction and Performance. International Education Studies, 8(1), $38-45$.

Musliza Mat Jusoh, Siti Noor Ismail \& Anis Salwa Abdullah. (2020). Kepuasan Kerja dan Komitmen Guru Sekolah Menengah Cemerlang Di Kelantan. JuPiDi: Jurnal Kepimpinan Pendidikan, 7(1), 77-90.

Nadiah Bani Amin, Amizawati Mohd Amir, \& Siti Farahhani Ismail. (2019). "Key Performance Indicators Tugas, Ganjaran dan Prestasi Kerja Guru Sekolah Kerajaan." JuPiDi: Jurnal Kepimpinan Pendidikan, 6(4), 38-60.

Nor Mohamad Zulhairi Ismail, Jamalul Lail Abdul Wahab \& Ruzita Md Hassan (2016). Kepuasan Kerja Guru dan Perbezaannya Berdasarkan Pencapaian Sekolah (Teacher Job Satisfaction and Performance Based Schools difference). Jurnal Personalia Pelajar, 19(1), 49-54

Noriati A. Rashid, Boon Pong Ying \& Wong Kiet Wah. (2010). Asas Kepimpinan dan Perkembangan Profesional Guru. Shah Alam : Oxford Fajar.

Norsimah Dasan \& Mohd Mahadzir Rahimi Mohamed Nawi. (2020). Hubungan Efikasi Kendiri Guru Dengan Prestasi Kerja Dalam Kalangan Guru Maktab Rendah Sains Mara (MRSM). Journal of Social Sciences and Humanities, 7(4), 173-187. 
Nurlila Abdul Wahab. (2018). Kualiti Pengajaran, Prestasi Kerja, Tekanan Kerja dan Hubungannya dengan Beban Tugas Guru Sekolah Menengah di Negeri Sabah. Tesis PhD, Universiti Malaysia Sabah.

Nurlina Mohd Puad, Mohd Daud Awang \& Ahmad Nasir Mohd Yusoff. (2018). Etika dan Tanggungjawab Pendidik dalam Profesion Perguruan Dan Cabaran Pendidik Masa Kini. Jurnal AL-ANWAR, Persatuan Bekas Mahasiswa Islam Timur (PBMITT), 6(2), 43-52.

Rinra Ayu Lismeida \& Rini Intansari Meilani. (2017). Kepuasan Kerja dan Kinerja Guru: Sebuah Studi terhadap Para Guru Smk Tersertifikasi di Indonesia (Job Satisfaction And Performance: A Study on State Vocational High School Certified Teachers in Indonesia). Jurnal Pendidikan Manajemen Perkantoran, 2(1), 57-65.

Rosnah Ishak dan Siti Nur Fatihah Rusman. (2018). Prestasi Kerja Guru dan Hubungannya dengan Faktor Beban Tugas, Persekitaran Kerja dan Personal: Kajian Kes Di Sebuah Sekolah Di Sabah. JuPiDi: Jurnal Kepimpinan Pendidikan, 5(1), 1-15.

Shah, N. H. \& Jumani, N. B. (2015). Relationship of Job Satisfaction and Turnover Intention of Private Secondary School Teachers. Mediterranean Journal of Social Sciences, 6(4), 313-323.

Samruhaizad Samian @ Samion \& Azahan Awang. (2017). Pendidikan Sebagai Komponen Kualiti Hidup Masyarakat Pinggir Bandar. Asian Journal of Environment, History and Heritage, 1(1), 267-280.

Steers, R.M. \& Porter, L.W. (1987). Motivation and Work Behavior. (4th ed). New York. Mc Grawhill Book Co.

Syed Kamaruzaman Syed Ali, Mohd Faithal Haji Hassan \& Habib Mat Som. (2017). Tekanan dan Kepuasan Kerja dalam Kalangan Guru Pendidikan Jasmani. Journal of Global Business and Social Entrepreneurship (GBSE), 1(1),122-135.

Usang Anak Ngrambang. (2012). Implikasi Kepemimpinan Pengajaran Pengetua, Kepuasan Kerja dan Pengajaran Berkesan Guru Terhadap Prestasi Peperiksaan Pelajar Sekolah Menengah Luar Bandar di Sarawak. Tesis Doktor Falsafah. Universiti Malaysia Sabah.

Yahya Buntat \& Zainuddin Masrom. (2003). Malaysia Amalan Etika Profesion Perguruan di Kalangan Guru-Guru Sekolah Kebangsaan Kampung Melayu, Kulai Johor. Satu Tinjauan. Jurnal Teknologi, 38(E) Jun. 2003, 65-74.

Yusof Jasmin @ Joseph Gimbad. (2007). Pengaruh Kepemimpinan Pengajaran Guru Besar Dan Pelaksanaan Tugas Guru Ke Atas Amalan Pengajaran Berkesan Di Sekolah Kurang Murid Negeri Sabah. Tesis Doktor Falsafah: Universiti Malaysia Sabah. 